\title{
L'Appétit Sauvage: The Blissful Utopia of Desire and Excess in Ben Jonson's Bartholomew Fair
}

\author{
Rui Rato \\ CETAPS / Charles University
}

\begin{abstract}
In Ben Jonson's Bartholomew Fair we find a realm of apparent freedom and levity, wherein the characters feel indulged to express themselves with far greater poignancy than it would happen in the regular world of law and order. The suspension of societal authority and structure brought about by this most voluptuous carnival leads to a dynamic flow of desire and want that normally would be restrained by good sense and justice, but as we find plainly in the play Justice is like a fish out of water amidst the ebullient effervescence of the appetites which define the Fair. Free to pursue their most sincere needs, pending toward extravagance as all desire which is taken to excess is wont to do, the characters quickly find themselves at home in this most savage of places, where there is nourishment to sate all palates, even the most depraved ones. But as even scoundrels dream of a better world, it may just be that Bartholomew Fair is that very world; where knaves and fools dance interminably in a merry-go-round, and where the impetus of Nature is uninhibited by unsophisticated reason. Does the utopian impulse, which I argue can be found within the play, come with this awareness of a need to binge and purge in a place which is accommodating to all kinds, and if so how does the appetite of the characters determine their utopian identity in accordance with the principle of nature found in need? To explore the nature of the Fair and the appetite which defines it, I will discuss primarily George Bataille's principle of general economy and sovereignty announced in The Accursed Share and Jacques Derrida's understanding of sovereignty in "From Restricted to General Economy: A Hegelianism Without Reserve". It can certainly be that the extraordinary impulse of consumption and excess which appears in the play can be discussed within the bounds of Utopian imagination, gifting disorder with the
\end{abstract}


laurels it much deserves, earned by the eager provision of essential perspective on an otherwise flat reality, restriction being far too often the key to a Dystopia.

Keywords: utopia, desire, freedom, appetite; sovereignty

Resumo: Na peça de Ben Jonson Bartholomew Fair deparamo-nos com um espaço autónomo de aparente leviandade onde as personagens expressam-se com uma liberdade e potência impraticável no mundo comum onde prevalece a lei e a ordem. A suspensão da autoridade e da estrutura de uma sociedade convencional que vem como resultado da dinâmica voluptuosa da feira, resulta na expressão complexa de desejo e querer que normalmente seria restringida pelo bom senso e pela justiça. Mas como vemos na peça a Justiça encontra-se como um peixe fora da água por entre os vapores escaldantes dos apetites que definem a feira. Livres para perseguirem as suas necessidades mais sinceras, que tendem a ser extravagantes tal como o desejo em excesso tende a ser, as personagens rapidamente sentem-se em casa neste espaço selvagem, onde qualquer gosto, qualquer perversão, pode ser saciado. Mas como até salafrários podem sonhar com um mundo melhor, é possível que semelhante mundo aqui se encontre na Feira de São Bartolomeu; onde os patifes e os tolos dançam de mãos dadas em círculos interminavelmente e onde o ímpeto da natureza não é inibido pela razão pouco sofisticada. Possui o impulso utópico, que eu afirmo existir na peça, esta consciência da necessidade humana de consumir e expurgar num espaço acomodador a todos os tipos de gente e se sim, de que forma é que o apetite das personagens determina o seu carácter utópico em relação direta com o princípio fundamental e natural do desejo? Para explorar a natureza da Feira e do apetite que a define, eu irei discutir primariamente os princípios da 'general economy' e 'sovereignty' de George Bataille, anunciado na The Accursed Share e a interpretação de Jacques Derrida sobre o conceito de 'sovereignty' encontrada em "From Restricted to General Economy: A Hegelianism Without Reserve". 0 impulso extraordinário de consumo e excesso presente na peça pode ser certamente discutido dentro dos âmbito da imaginação utópica, presenteando a desordem com o louvor que esta merece, distinção adquirida pelo seu poder de providenciar liberdade e perspetiva essencial numa realidade que seria de outra forma plana, uniforme, irreal; a restrição sendo frequentemente a chave para uma distopia.

Palavras-chave: utopia, desejo, liberdade; soberania 


\section{Introduction}

In this brief essay I wish to contemplate the nature of desire as it connects with the idea and pursuit of utopia, food and the fulfilment of appetite. Appetite is an important word in my thinking, as I believe it holds the key to a greater understanding of the essence of desire, which in turns speaks to the elemental strength of the need for constant development and growth portrayed so eloquently in the utopian impulse. It is my understanding that Ben Jonson's Bartholomew Fair constitutes the perfect playground wherein the characters find forms of expression that would naturally be shunned in a world where severe restrictions, good sense and tradition, apply. The whole play revolves, in my view, around the satisfaction of desire, all kinds of desire and often without any limitations; this is desire taken to excess, something which George Bataille discusses convincingly in his idea of general economy. I believe that Bataille's philosophy, from The Accursed Share, is important not only in understanding the origin but also the consequence of human want, with Ben Jonson's play serving as the literary context for this discussion. General economy pertains to comprehend the essence of desire itself, of the powerful hunger which drives, of being, to consume and to own, in relation to the various elements and entities which constitute reality. This makes it an economical as well as philosophical concept about exchange, influence and drive. Desire is linked to a person's identity, so that it vies to satisfy individual needs, but when the individual body has energy in excess of its need, that extra energy becomes luxury. Bataille argues that this luxury must needs be acknowledged, not suppressed, and spent in a free manner, without being halted by a preoccupation with production and accumulation. Luxury, then, is a reflection of the effervescence of life which cannot be contained: “(...) [W] hat general economy defines first is the explosive character of this world, carried to the extreme degree of explosive tension in the present time. A curse obviously weighs on human life insofar as it does not have the strength to control a vertiginous movement" (1991:40).

Yet, a proper release of excess energy often goes to considerable lengths merely for the sake of itself. Bataille exemplifies this excess in eroticism, where the sexual act is had not with the intention of reproduction, but to experience the feeling of stress and release 
which is key to the extraordinary sensation of pleasure and joy. Likewise, our sexuality is inextricably associated with our identity, so that a momentous sexual experience serves both as mirror and challenge to who we are. This impulse also frequently finds its greatest fulfilment when it is transgressive, and when it's done only with pleasure in mind, which is to say when it embraces its volatile and exuberant nature. To deny the potency of desire is folly, yet it is understandable to want to do so, because one's pleasure taken to excess, though meaningful and natural, carries with it a sense of great consequence.

(...)[S]exual reproduction is the occasion of a sudden and frantic squandering of energy resources, carried in a moment to the limit of possibility (...). This squandering goes far beyond what would be sufficient for the growth of the species. It appears to be the most that an individual has the strength to accomplish in a given moment. It leads to the whole-sale destruction of property - in spirit, the destruction of the bodies as well - and ultimately connects up with the senseless luxury and excess of death. (1991: 35)

This squandering is a wasting of excess energy that must be dissipated continually in order to ensure the stability of the subject, but it often takes a rather extreme representation which destabilizes the vision of a regular and conventional person (it upsets the expectations of control and order). However, sensuous appetite is interested in more than just the mere sexual act, and it finds its footing, as Bataille explains, in "the scandals of death and the eating of meat" (1991:38) - this is to say in games of power which concern one's life or death and with food, particularly food which has been sacrificed for one's needs (along with the primal connection of biting and tearing flesh as nourishment and defence; Bataille discusses the tiger as a symbol of the extraordinary depth and scale of human appetite that is also predatory). These issues abound in Bartholomew Fair as it is the perfect environment for the expression of such excess in the form of individual fetishes, constituted on relations of control and consumption between the characters, which are fundamental toward a critical perception on issues of identity and pleasure. The energies of life cannot be contained, to the detriment of an expectation of justice and of civilized life.

My analysis of the play is predicated on this understanding of a universal movement 
of energy and the contrast between general economy (the universal exuberance of life as is evidenced, for instance, in the sovereign power of the sun which gives freely without expecting return) and restricted economy (the restricted operations of an individual being which hungers and wants, whose exchanges are designed to stave off a personal lack). As humanity is encompassed in this primeval current of energy, it develops an awareness of its own desire which is insatiable. The exuberance of life is intoxicating to a being which is inherently individual and lacking, always in need, never entirely satisfied but compelled to become whole. The stimulation and satisfaction of certain urges in excess, namely that of appetite, allows the disconnected being to experience an ever increasingly deeper feeling of connection with this primordial pull of general economy, thus allowing him to break from his natural disconnected state into a temporary sense of unfiltered joy. The act of eating, in its multiple iterations, brings the characters together and connects them like little else might (although it can and does also tear them apart - hence the complexity of the dynamic in question). To attempt to repeatedly satisfy the ultimate appetite for a sense of communion, regardless of the fact that it is impossible (or perhaps because of it), is a profoundly existential act, and it sometimes brings the characters in the play great personal profit, necessarily at the expense of others, and sometimes it leads them down to ruin. This tension, enunciated by Bataille's philosophy, constitutes the basis of my reading of the play.

\section{The Representation of Desire in Bartholomew Fair}

How does the play by Ben Jonson provide context for this very gamey discussion? In it, the characters are given free rein to attempt to fulfil their desire in an environment wholly permissive in that manner, with each of their visions of a better world, their personal utopias, coming into play unrestrained. As there is no other law in Bartholomew fair except for the laws of the trade, of the market, of profit, and consumption, having in view solely the fulfilment of any sort of want (the market standing as an intuitive form of communication and regulation), the characters are free to become the vehicle for their own insatiability, embodying the very potency of life in the act of creation, and destruction. This is the universal movement of energy that general economy proposes to exist and which has 
a considerable impact on human development. The play, in that sense, depicts the clash between the constant starvation of the individual, the individual want, and the luxury of an environment that promises the fulfilment of all fantasies. Luxury, then, provokes the individual to effect the consumption of his desire, but appetite has a cost, and eating is an uneven ritual; the choice meat tends to go to the most cunning animal. The fair is perfectly natural and balanced, which is to say that all things being equal, the individual with the greater strength of will, with the greatest appetite, has his way. A real sense of balance in nature has always required victims, and the fair, being a place of no real restriction but instead of absolute freedom, is only too happy to oblige. There is a denial and unfiltered sense of causality which is unimpeded by unsophisticated reason.

At the core of this need for expression is material desire, leading into a sense of communion and celebration which perhaps only extreme expression can provide, a release that prefigures what I would like to term the creation of a primal utopia - a vision of humanity stripped of moral restrictions. All appetites are welcome: food, drink, sex, gambling, violence and even artistic expression - evidence that the natural impulse to consume in the characters is not merely base, but also intellectual; an impulse made more complicated because of humanity's higher critical faculties. The fact that these needs have to be purchased, namely with money, makes it very clear that this celebration comes with a cost, and it is not a place for the breaking down of social barriers and unification of people in an idealized environment of merrymaking and laughter, as in Bakhtin's theory of the Carnivalesque (Bakhtin 1984). Or rather, the laughter does exist, but it is often the laughter of scorn and derision, used to separate the individual members into a hierarchy. It is then an environment of division and differentiation. Insatiable desire is what keeps it running, well-oiled, the mechanism for the procurement of individual freedom which perhaps can only be found in a place just like Bartholomew Fair, but by which momentum is, by its very nature, wild and out of control.

It is interesting to explore the way in which the characters develop their tastes in the play and the shape which it takes having as its aim the consummation of an appetite. Consumption, as Bataille explains, is not only important, it is an inevitability. Faced with 
this perspective, the choice remains only on how this consumption will occur. The characters in the play tend to choose instinctively, and what marks this place as a primal utopia is that they consume and expend their energies luxuriously, free from the boundaries of conventional control, which is an only fitting integration of the general economy principle into what would ordinarily be restricted exchanges - the characters come into their own. The fair is an absolutely welcoming environment for all kinds of costumers: rich and overindulgent spenders of currency who find the goods available for purchase only too enticing; the booth owners who profit extensively from such marked interest in their wares; essential fetishists whose existential needs are met only in the most extreme of expressions, such as that of impossible bickering, swearing, and brawling; women who have grown tired of the servitude of marriage and seek freedom elsewhere; and the pickpockets who are only too happy to relieve anyone of their immediate disposable income. There are a few examples which stand out and which I would like to call attention to, although it is only fair to say that the model of understanding which I am alluding to could probably be applied to all characters in the play.

\subsection{Ursula and Win: An Appetite Extraordinaire}

At the beginning of the play Win-the-fight, a young lady who is pregnant, and her daring male-counterpart Littlewit, decide, upon hearing about the Fair which is occurring, that they could really eat some roasted pig meat. As such, they contrive to circumvent Win's mother's Puritan restrictions on pleasure by using the well placed argument of Win's pregnancy as proper leverage, to convince Dame Purecraft that indeed it was a matter of some urgency in regard to eating, and possibly enjoying, said pig. They are successful in their argument, as Dame Purecraft becomes convinced that her "daughter Win-the-Fight is visited with a natural disease of women," called "a longing to eat pig" (Jonson 1614: 1.6.378), but are unexpectedly joined not only by Win's mother herself but also by her favourite preacher, Zeal-of-the-land Busy, whose particular appetite was for hypocrisy, one could argue, as they both go with them in order to safeguard their souls while in the "seat of the Beast" (idem: 3.6.40). In truth, at least in Zeal's case, he's going there to sustain his 
voracious appetite for wine and pig (and guilt). And so they all wander into the Fair and find a tent which serves their coveted prize. It is easy to imagine them sitting down and enjoying a sumptuous meal, always pretending to a deep, religious consternation over the unfortunate temptations which the weak flesh is subject to in the mortal world. Or perhaps in the frenzy of the animal devouring its prey, their face would show their ugly lust for the sensations which only genuine surrender provides. Of course, in typical Bartholomew Fair's fashion, by the end of the meal, and now that they have had their fill of food and drink, Win and her partner plan to "be rid" of their Guardians, and engage in all the other pleasures contained within the Fair, which are numerous. As Littlewit says, "Now you ha' begun with pig, you may long for anything, Win" (idem: 3.6.7). An appetite that keeps growing and growing; eating the pig awoke desire in Win. It is interesting that as Littlewit leaves her to prepare for his puppet show, Win's longings take a turn for the wicked as she is persuaded by Mooncalf, a boy who doubles as a pimp in Ursula's booth, that marriage is slavery and prostitution is freedom, that a lady comes into her own most meaningfully when donning the skirts of a prostitute. At this proposal Win grows bold with her nascent and overwhelming passion for freedom, and freedom to be, and feels that he strikes a persuasive argument; she consents to becoming a prostitute having Mooncalf as her pimp. Only too quickly does she realize that her potent manifestation of hunger condemned her from being enslaved from one man to another and that, though her desire ran true, her stumbling appetite might have precipitated her into remaining a victim; a fact which does not dismiss the validity of her impulse. It is, if anything, a reminder that even in a place of complete freedom, everything has a cost. As Paul Cantor in "The Law Versus the Marketplace: Spontaneous Order in Jonson's Bartholomew Fair" (2009) says,

[The play] is Jonson's image of the new world of capitalism - everything has its price in money and everything is up for sale. To emphasize the point, and suggest that even human flesh can be bought in the marketplace, Jonson makes prostitution an integral part of the fair. (181)

The particular booth that they visited belonged to Ursula, a rather large woman, both in ambition as well as in physical appearance. She is yet another example of a 
character ruled by an overwhelming need, mostly a need for financial profit, which is her particular obsession. She attempts to make money by doubling her tent as a place to eat and drink, and as a whorehouse, which calls to mind Jonathan Hayne's explanation that the fair as "the marketplace [is] a place for accumulation [and loss], not festivity" (1984: 649). The stakes are higher here than mere levity and simple enjoyment, as there is always a price to pay even for mere participation. It becomes philosophical when the connection between our desires and our identity, and the natural consequence of the transparency and potency of such desire, is brought to bear in the narrative - something which the play does exceedingly well. The notion that pleasure has a cost merely makes the idea more complicated, but it also makes it more profitable as the sensation is more genuine when there is more at stake -at the most extreme one's very identity. What is of particular interest for us regarding Ursula is that she is a prime cut of an example of animalism in the play, as in her singular pursuit of profit she becomes gross and distorted. She sells pigs for a living, and is in turn compared to a pig, as though her very features were transformed by her desire. One might claim that her appetites defined her. As Justice Overdo, a central character in the play, himself remarks, "This pig-woman do I know [...] This is the very womb and bed of enormity, gross, as herself!" (Jonson 1614: 2.3.68, 100-1).

Later in a far more provocative scene, Quarlous and Winwife, two other rogues who peruse the fair looking for satiety, amuse themselves by mocking Ursula, with Quarlous stating: "Nay, she is too fat to be a Fury, sure; some walking sow of tallow!" (idem: 2.5. 701). Once again she is compared to a pig, this time to a mature grown female pig. To this she replies, “Aye, aye, gamesters, mock a plain plump soft wench o' the suburbs, do, because she's juicy and wholesome" (idem: 2.5. 75-6). Now, is she describing herself, or the various kinds of meat she sells? What a curious choice of words, as describing herself as 'juicy and wholesome' is rather suggestive of flavour and texture, like she herself is aware that she is like a pig. In her identity all the elements are meshed into a single current: her body, that of the pigs she sells and of the women she prostitutes; these are all Ursula, all created and put to market for the single purpose of giving voice to her passion for more. It is her excessive 
desire that makes her like a pig, and that point makes her and Busy and Win share and have something in common.

\section{The failure of Justice and the Impossibility of Sovereignty}

Regarding the epilogue of the play Richard Burt states that,

Jonson clearly presumes that James will make an affirmative judgment of the play, and the fact that James alone has the authority to judge whether or not the Fair and the play are profane affirms the king's power all the more. In this respect, poetics and politics are mutually authorizing: under the rubric of dramatic art, the king licenses the subversion of authority within the Fair, and that subversion in turn issues in an invitation to James to reassert his political authority. (1987: 533)

Considering the historical, social and political context of the play, in early $17^{\text {th }}$ century England there was a considerable tension between the Puritans and James I in regards to cultural entertainment, such as the theater and fairs (idem: 530). The Puritans, much like Zeal-of-the-land Busy, felt that these forms of entertainment were too profane. However, the early Stuarts thought it wise to allow these forms of cultural expression, so as to grant the people a chance to vent their daily tensions, instead of directing them towards the monarchy. Indeed, they promoted the theater quite extensively, though not completely, as it seems that many plays were censored on account of the fact that they did not, for instance, promulgate the interests of the king. Yet, this authority which Jonson gives to the king in the epilogue of the play he seems to take back by the end of it, just as Burt says on the quotation. Perhaps it was intended as a sort of challenge or stimulation of the monarchy for it to regain political power and subvert market dynamics that Jonson was opposed to (idem: 540), for this economic principal of endorsing mostly popular forms of entertainment (baser appetites) contradicted his perception of an elite sense of culture (a more refined taste). Yet we are left wondering by the end, right along with Jonson (idem: 552), if indeed any kind of authority can actually instill a balance between culture and capital. In that sense, there is a conflict between the desired harmony and a real force which shatters the hope for balance. Applying the theoretical notion of sovereignty, with its 
inherent impossibility, we might achieve a more comprehensive appreciation of the problem; an understanding, in fact, that no one major figure of authority can actually regulate society, much to the sovereign's dismay, for the world is a far more complex system than what is afforded by human expectation. Human sovereignty then appears destined to fail, and in the play the character of Justice Overdo is the representative of the principle of sovereignty.

\subsection{Justice Overdo}

Justice Overdo is an austere judge who disguises himself as a nobody in the environment of the fair so that he may best spot out the 'enormities' he believes himself capable of subverting. These crimes and excesses, in fact, belong to an entire dynamics whose real scope utterly eludes him, and he is ultimately frustrated in his enterprise by a predictable impotence in the face of the very enormities he sought to redeem. A significant example of this is when Justice Overdo is mistaken for a criminal and is imprisoned, something which is attributable to his blind thirst for the enforcement of sovereign justice. This is ironic, as he was moved by something he cannot really control (his desire) into attempting to control a similar impetus in the other characters, with the consequences being rather dire. As James Robinson affirms: "The reformer Overdo, who cannot distinguish a gentleman from a thief, is thus identified as a rogue of the Fair" (1961: 73). This is also unmistakable proof that whatever law exists in the fair is itself ineffective in the ideal sense of identifying and punishing those who are truly the criminals. Justice's incarceration is a double failure, both he and the legal system are blind (exhibiting the idea of "Justice is blind" in a satirical light), and the laughter elicited by the irony of his predicament serves only to reinforce the idea that there are forces which will not be halted.

In Justice's case his chosen dish was reformation and execution of his purported sovereign power, as previously stated. Unfortunately for him, he was rather quickly overwhelmed by his environment. Justice is naturally the representation of sovereignty in the play, for he stands for the rule of law, in this case monarchic law, which is but one example. He attempts to control major events and this impulse is a concrete example of 
Royal sovereignty, which is ultimately virtually impossible to exercise in a marketplace which effectively enables and liberates its consumer's desires. That he fails is part of the process of sovereignty, as it is a system meant to fail in human hands, which is another way of saying that it cannot escape an inevitable loss of meaning, a loss of authority and control. It is like a power too great to wield. As Jacques Derrida says,

Sovereignty dissolves the values of meaning, truth and a grasp-of-the-thing-itself. This is why the discourse that it opens above all is not true, truthful or 'sincere'. Sovereignty is the impossible, therefore it is not, it is [...] "this loss". (1994: 270)

The sovereign, a title that is imprecise, seeks control over everything in his dominion and of all his subjects, but this is an illusion, this is impossible. One cannot control everything, one cannot see everything and know everything, and the King is but a man, one man. This natural limitation, the impossibility of success and subsequent failure is the absence that Derrida speaks of (idem: 270), from which we can apprehend the presence of sovereignty. There is a distance between the purported sovereign and sovereignty.

The final scene is perhaps the most poignant example of the failure of Justice to subvert the impulse toward total freedom, which I see as utopian, present in the Fair and its most sincere inhabitants. He eventually comes out as Justice Overdo by doing away with his disguise, with the intention of inflicting "righteous justice" upon all whom he perceives as being wicked, and to amend all "enormities", in the form of a correctional speech which would right all moral and legal wrongs. This plans falls entirely to the ground, as in his grand debut his momentum is considerably interrupted when he discovers that his own wife, who had also been charmed by Mooncalf's rhetoric, had now become a prostitute, who happened to be, at the time of Justice's unveiling, vomiting on the ground. She pitifully cries out his name like a lost child who's behaved badly, and was hurt as a result, and so he instead becomes a mute. Of this Paul A. Cantor says: "[t]he complete collapse of his regime occurs when he goes to punish a group of prostitutes and discovers that one of them is his own wife" (2009: 193-4). This reveals the fundamental incapacity of the sovereign (and of his agents) in curbing the affluence of life, as it begins to dawn on Justice Overdo just how 
out of his control the full scope of the situation really is. Instead, his correctional speech is taken over by Quarlous, someone far more at ease in a world that is openly and frankly unjust in its elemental justice and mysterious in its whims. The attempt to control reality by simply assuming the moral high-ground was doomed to fail, but it was also the constant denial in regard to the true nature of his own desire that contributed to this. He held himself to an impossible standard of perfect harmony and absolute justice and stumbled into a place which is absolutely free (even as it constricts). He was shattered and undone by the fair because he had failed to understand exactly what drove him. His naivety was his undoing. As Georges Bataille seems to indicate,

Incomprehension does not change the final outcome in the slightest. We can ignore or forget the fact that the ground we live on is little other than a field of multiple destructions. Our ignorance only has this incontestable effect: it causes us to undergo what we could bring about in our own way, if we understood. It deprives us of the choice of an exudation that might suit us. Above all, it consigns men and their works to catastrophic destructions. (1991: 24)

This quote from Bataille further contextualizes a vision of reality in which Justice Overdo is not an isolated case, a freak occurrence, but an incontrovertible example of a greater phenomenon that expands far beyond one individual.

\section{Conclusion}

This leads me to conclude that the pursuit of honest pleasure, much as it may reflect negatively and provoke loss of meaning on the individual, even as one must risk death in order to achieve one's vision of a more significant world, is, in fact, the impetus behind a vision of utopia that adequately accounts for human complexity, with all its contradictions, its essential violence. This is a pleasure sought having at its base the material: food, the touch, the sound, and the extravagant passions. If Bartholomew fair is to be perceived as the mainframe upon which rests this primal utopia, as I have termed it, this Eden of desire and expression, of freedom, then it is also true, as the play suggests, that justice as a form of restrictive control has no real place in its dealings, in its essential fulfilment. The market 
balances itself, as too much violence would fundamentally undermine the character's capacities to keep consuming, and fundamental peace would mean an apathy which harkens to a state of non-living; dead while still alive. It is the conflict that generates profit, both financial as well as existential; conflict is the source of life just as it is the source of meaning. Justice, then, impossible and impractical in human hands, is the absence by which we denote the presence of real sovereign power: desire, which tends to want more and more, a need which does not stop growing; a desire which has, at its source, the effervescent pressure of life as it is discussed in Bataille's general economy. If this is so, then it may very well be utopia's ultimate purpose the recognition of the fundamental presence of chaos and disorder as the integral constitutive part in the elaboration of freedom and its coveted individual and collective fulfilment; maximum pleasure requiring total abandonment. Acceptance of this natural, if volatile, passion and state of affairs might be the only real meaningful act left for justice to perform, if it aims to create a sincere dialogue with the people it purports to represent, although the efficacy of such a dialogue is uncertain. 


\section{Works Cited}

Bakhtin, Mikhail (1984), "Introduction", in Rabelais and His World , translated by Helène Iswolsky, Bloomington and London, University of Indiana Press, 1984, 1-51.

Bataille, Georges (1991), “The Meaning of General Economy”, in The Accursed Share: An Essay on General Economy, translated by Robert Hurley, New York, Zone Books, 19-26.

Burt, Richard A (1987), “'Licenced by Authority': Ben Jonson and the Politics of Early Stuart Theater", in English Literary History 54.3., 529-560, JSTOR. <http://www.jstor.org/stable/2873220> (Last accessed 1 August 2014).

Cantor, Paul A (2009), “The Law Versus the Marketplace: Spontaneous Order in Jonson's Bartholomew Fair", in Literature and the Economics of Liberty: Spontaneous Order in Culture, eds. Paul Cantor and Stephen Cox, Auburn, AL: Ludwig von Mises Institute, 167-224.

Derrida, Jacques (1994), "From Restricted to General Economy: A Hegelianism Without Reserve", in Writing and Difference, translated by Alan Bass, Chicago and London, Routledge, 251-277.

Haynes, Jonathan (1984), “Festivity and the Dramatic Economy of Jonson's BartholomewFair", in English Literary History 51.4., 645-68, JSTOR. http://www.jstor.org/stable/2872778 (Last accessed 1 July 2014)

Jonson, Ben (1995), "Bartholomew Fair", in The Alchemist and Other Plays, ed. Gordon Campbell, Oxford, Oxford University Press, 327-433.

Robinson, James E. (1961), “Bartholomew Fair: Comedy of Vapors”, in Studies in English Literature, 1500-1900 1.2., 65-80, JSTOR. <http://www.jstor.org/stable/449340> (Last accessed 3 July 2014). 
Rui Rato

Rui Rato studied Cinema and Audiovisual Media in "Escola Superior Artística do Porto" (ESAP) and has recently finished writing his MA dissertation in Anglo-American Studies at "Faculdade de Letras, Universidade do Porto" (FLUP), on Metamorphosis in Thomas Harris's The Hannibal Lecter Trilogy. He is currently doing a $\mathrm{PhD}$ at Charles University, Prague, on the subject of Eroticism as Transgression in Oscar Wilde's The Picture of Dorian Gray and 19th Century English literature and is also a collaborator at CETAPS. 